\title{
Nanostructured $\mathrm{CeO}_{2}-\mathrm{Al}_{2} \mathrm{O}_{3}$ Catalytic Powders for $m$-Xylene and Toluene Combustion
}

\author{
Luu M. Dai ${ }^{1}$, Dao Ng. Nhiem ${ }^{1}$, Duong Th. Lim² ${ }^{2}$ and Nguyen D. Van ${ }^{1, *}$ \\ ${ }^{1}$ Institute of Materials Science, Vietnam Academy of Science and Technology, 18 Hoang Quoc Viet, Cau Giay, Hanoi 10000, Vietnam \\ ${ }^{2}$ Institute of Geography, Vietnam Academy of Science and Technology, 18 Hoang Quoc Viet, Cau Giay, Hanoi 10000, Vietnam
}

\begin{abstract}
The bee's nest-like nanostructured $\mathrm{CeO}_{2}-\mathrm{Al}_{2} \mathrm{O}_{3}$ powders were synthesized by combustion method using polyvinyl alcohol as a fuel and their catalytic activity were tested in the $m$-xylene and toluene combustion. The results showed that the catalytic reaction temperature increased monotonically from 200 to $250^{\circ} \mathrm{C}$ and from 250 to $300^{\circ} \mathrm{C}$ for the $90 \%$ conversion of $m$-xylene and toluene, respectively, with the calcination temperature in the range of $450-850^{\circ} \mathrm{C}$. For both combustions, the sample calcined at $450^{\circ} \mathrm{C}$ with a bee's nest-like nanostructure and average pore size of $800 \mathrm{~nm}$ exhibited the highest catalytic activity. Among the samples calcined at $850^{\circ} \mathrm{C}$, the lowest catalytic reaction temperature for the $90 \%$ conversion of $m$-xylene and toluene of 250 and $300^{\circ} \mathrm{C}$, respectively, was found with the sample having the equimolar ratio of Ce/Al. [doi: $10.2320 /$ matertrans.M2013056]
\end{abstract}

(Received February 12, 2013; Accepted April 3, 2013; Published May 25, 2013)

Keywords: nanostructured $\mathrm{CeO}_{2}-\mathrm{Al}_{2} \mathrm{O}_{3}$, catalyst, m-xylene combustion, toluene combustion, combustion method

\section{Introduction}

In the field of organic pollutant treatment, the elimination of volatile organic compounds (VOCs), especially carcinogens like benzene, ethylbenzene, xylene and toluene, has been studied intensively. ${ }^{1-3)}$ For the combustion of these compounds, the catalytic combustion was frequently used due to the fact that it exhibits high conversion efficiency and causes no side toxic pollutants. To eliminate $m$-xylene and toluene, in particularly, one of the current research trends is finding low cost alternatives, for examples, carbon-based materials, mixed oxides, ... to commonly used noble metalbased catalysts. ${ }^{4-6)}$ Among these materials, ceria and ceriabased mixed oxides such as $\mathrm{MnO}_{\mathrm{x}}-\mathrm{CeO}_{2} / \mathrm{TiO}_{2}, \mathrm{CuO} / \mathrm{CeO}_{2}$, $\mathrm{CuO}-\mathrm{CeO}_{2} / \mathrm{Al}_{2} \mathrm{O}_{3} \ldots$ were already investigated. ${ }^{7-11)}$ Owing to the high oxygen storage capacity of $\mathrm{CeO}_{2}$ and the high surface area and thermal stability of $\mathrm{Al}_{2} \mathrm{O}_{3}, \mathrm{CeO}_{2}-\mathrm{Al}_{2} \mathrm{O}_{3}$ mixed oxide system were used as catalysts for the oxidation of toxic gases such as $\mathrm{NO}$ and $\mathrm{CO}{ }^{12,13)}$ Recently, nanostructured $\mathrm{Pt} / \mathrm{CeO}_{2}-\mathrm{Al}_{2} \mathrm{O}_{3}$ catalysts were reported to be used for total oxidation of VOCs including toluene and mixed xylene. ${ }^{14)}$ To date, to our knowledge, no work has been reported on using for the $\mathrm{CeO}_{2}-\mathrm{Al}_{2} \mathrm{O}_{3}$ system as a catalyst for $m$-xylene while for the case of toluene only one research has been published. ${ }^{15)}$

In this work the catalytic activity in the $m$-xylene and toluene combustion of the bee's nest-like nanostructured $\mathrm{CeO}_{2}-\mathrm{Al}_{2} \mathrm{O}_{3}$ powders synthesized by combustion method using polyvinyl alcohol and metal nitrates as starting materials was presented. The effects of calcination temperature and $\mathrm{Ce} / \mathrm{Al}$ ratio on the $m$-xylene and toluene conversion of samples were also investigated.

\section{Experimental}

\subsection{Synthesis of catalyst}

The synthesis of nanostructured $\mathrm{CeO}_{2}-\mathrm{Al}_{2} \mathrm{O}_{3}$ powders by combustion methods from metal nitrates and polyvinyl

*Corresponding author, E-mail: vannd@ims.vast.ac.vn alcohol was described elsewhere. ${ }^{16)}$ In a typical procedure, analytical grade nitrates of cerium and aluminium ions with desired $\mathrm{Ce} / \mathrm{Al}$ molar ratio were dissolved in a solution of PVA with the metal cations/PVA molar ratio fixed at $1 / 3$. The mixture was adjusted to the $\mathrm{pH}$ of 4 and then heated at $80^{\circ} \mathrm{C}$ until a viscous gel was obtained. This gel was calcined at 450 , 600,750 and $850^{\circ} \mathrm{C}$ for $2 \mathrm{~h}$. The morphology of prepared samples was characterized by field-emission scanning electron microscopy (FE-SEM, Hitachi S 4800 microscope).

\subsection{Catalytic activity test}

The prepared samples with different calcination temperatures and $\mathrm{Ce} / \mathrm{Al}$ molar ratios were tested for $m$-xylene and toluene combustion. For combustion experiments, a $0.2 \mathrm{~g}$ of samples was loaded inside a micro-flow reactor with the catalytic layer thickness of $0.6 \mathrm{~cm}$. Then, $2000 \mathrm{ppm}$ of saturated $m$-xylene or toluene vapour in dry air was passed through catalytic layer with the flowing rate of $10 \mathrm{ml} / \mathrm{min}$. The catalytic reactions of $m$-xylene and toluene were carried out at temperatures in the range from 50 to $400^{\circ} \mathrm{C}$. The conversion rate of these two compounds can be calculated from following formula:

$$
\mathrm{R}_{\mathrm{VOC}}=\left[\left(\mathrm{C}_{\mathrm{VOC}(\text { in })}-\mathrm{C}_{\mathrm{VOC}(\text { out })}\right) / \mathrm{C}_{\mathrm{VOC}(\mathrm{in})}\right] \times 100 \%
$$

where, $\mathrm{R}_{\mathrm{VOC}}(\%)$ is the conversion rate of $m$-xylene or toluene; $\mathrm{C}_{\mathrm{VOC}(\mathrm{in})}$ and $\mathrm{C}_{\mathrm{VOC}(\text { out }}$ are the $m$-xylene or toluene concentrations in the inlet and outlet gas, respectively.

\section{Results and Discussion}

\subsection{Synthesis of the bee's nest-like nanostructured $\mathrm{CeO}_{2}-\mathrm{Al}_{2} \mathrm{O}_{3}$ powders}

The structural, morphological properties and the effects of preparative conditions including the $\mathrm{Ce} / \mathrm{Al}$ molar ratio and calcination temperature on phase formation, phase composition and morphology of the bee's nest-like nanostructured $\mathrm{CeO}_{2}-\mathrm{Al}_{2} \mathrm{O}_{3}$ powders were described in details in Ref. 16). It was found that for samples with $\mathrm{Ce} / \mathrm{Al}$ molar ratio of $5 / 5$ calcined at temperatures below $750^{\circ} \mathrm{C}$, no crystalline phases were detected and the pure fluorite structure $\mathrm{CeO}_{2}-$ 
(a)

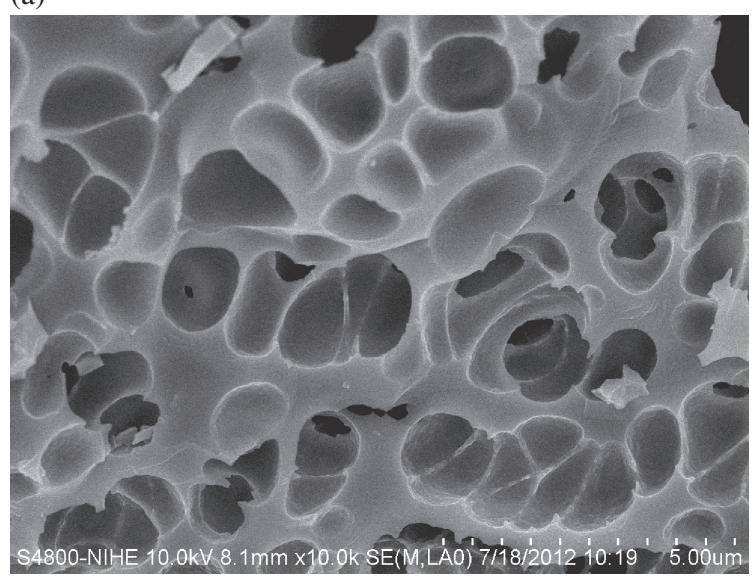

(b)

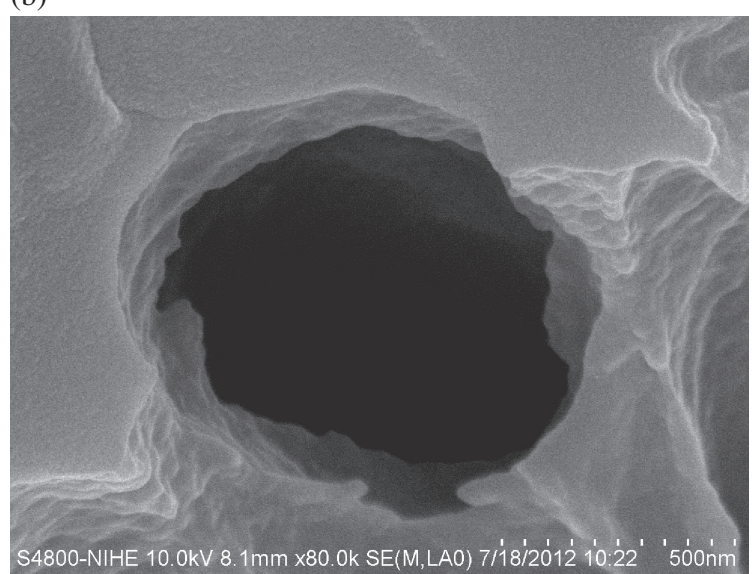

Fig. 1 FE-SEM images at the magnification of (a) 10000 and (b) 80000 of $\mathrm{CeO}_{2}-\mathrm{Al}_{2} \mathrm{O}_{3}$ sample with $\mathrm{Ce} / \mathrm{Al}$ molar ratio of $5 / 5$ calcined at $450^{\circ} \mathrm{C}$.

based phase fully crystallized was obtained only when the calcination temperatures of over $850^{\circ} \mathrm{C}$. In addition, the bee's nest-like nanostructure was observed in samples calcined at temperatures in the range of $500-850^{\circ} \mathrm{C}$ and no longer existed for the samples calcined at $950^{\circ} \mathrm{C}$. In the present work, the bee's nest-like nanostructure with three-dimensional pore arrangement was also found in the sample with $\mathrm{Ce} / \mathrm{Al}$ molar ratio of $5 / 5$ calcined at $450^{\circ} \mathrm{C}$ (Fig. $1(\mathrm{a})$ ), the temperature from which no further changes in thermogravimetric (TG) curve was found. ${ }^{16)}$ The average pore size of this sample is $800 \mathrm{~nm}$ (Fig. 1(b)) and larger than those of samples calcined at higher temperatures.

\subsection{Effects of calcination temperature on the $m$-xylene and toluene conversion}

The prepared samples with $\mathrm{Ce} / \mathrm{Al}$ molar ratio of $5 / 5$ calcined at $450,600,750$ and $850^{\circ} \mathrm{C}$ were tested for catalytic activity in $m$-xylene and toluene conversion. From Fig. 2(a) one can realize that, for the case of $m$-xylene combustion, with the same conversion efficiency of $90 \%$, the catalytic reaction temperature increased monotonically from 200 to $250^{\circ} \mathrm{C}$ with the calcination temperature ranging from 450 to $850^{\circ} \mathrm{C}$. Similarly, for the toluene combustion, the conversion efficiency of $90 \%$ was obtained at temperatures in the range of $250-300^{\circ} \mathrm{C}$ for the sample calcined at $450-850^{\circ} \mathrm{C}$, respectively (Fig. 2(b)). Compared to non-noble metal
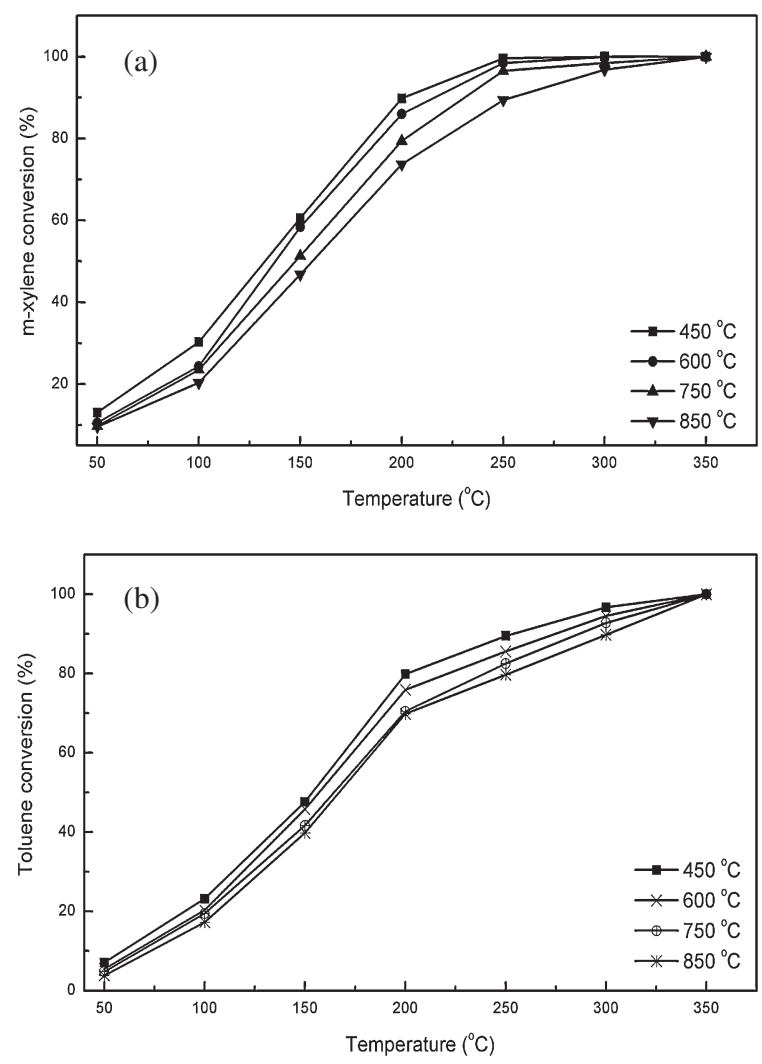

Fig. 2 Catalytic conversion of (a) $m$-xylene and (b) toluene over nanostructured $\mathrm{CeO}_{2}-\mathrm{Al}_{2} \mathrm{O}_{3}$ powders with $\mathrm{Ce} / \mathrm{Al}$ molar ratio of $5 / 5$ calcined at $450,600,750$ and $850^{\circ} \mathrm{C}$.

catalyst systems such as activated carbon fibre impregnated with transition metals $(\mathrm{Co}, \mathrm{Cr}, \mathrm{Ni}$ and $\mathrm{Cu})$ for the $m$-xylene catalytic combustion, the catalytic reaction temperature of the present catalytic system was lower for the sample calcined at $450^{\circ} \mathrm{C}$ and was nearly the same for the sample calcined at $850^{\circ} \mathrm{C}^{5)}$ The catalytic reaction temperature of $200^{\circ} \mathrm{C}$ required for $90 \%$ conversion of nanostructured $\mathrm{CeO}_{2}-\mathrm{Al}_{2} \mathrm{O}_{3}$ powders calcined at $450^{\circ} \mathrm{C}$ for $m$-xylene catalytic combustion was also lower than that of active $\mathrm{CeO}_{2}$ catalyst for $p$-xylene $\left(230^{\circ} \mathrm{C}\right)$ oxidation and of $\mathrm{CeO}_{2}$ nanocubes for $o$-xylene conversion $\left(210^{\circ} \mathrm{C}\right)$ and was equal to that of nanostructured $\mathrm{Pt} / \mathrm{CeO}_{2}-\mathrm{Al}_{2} \mathrm{O}_{3}$ catalysts for mixed xylene combustion. ${ }^{7,8,15)}$ Thus, it is reasonable to use our nanostructured $\mathrm{CeO}_{2}-\mathrm{Al}_{2} \mathrm{O}_{3}$ powders with high content of $\mathrm{Al}(\mathrm{Ce} / \mathrm{Al}$ molar ratio of 5/5) for $m$-xylene combustion due to their high catalytic activity and cost effectiveness. For the toluene combustion, the required temperature for $90 \%$ conversion of the bee's nestlike nanostructured $\mathrm{CeO}_{2}-\mathrm{Al}_{2} \mathrm{O}_{3}$ powders was lower for the sample calcined at $450^{\circ} \mathrm{C}$ and, for the sample calcined at $850^{\circ} \mathrm{C}$, was closed to that reported for $\mathrm{Pt} / \mathrm{CeO}_{2}-\mathrm{Al}_{2} \mathrm{O}_{3}$ nanocatalysts and for the $\gamma-\mathrm{Al}_{2} \mathrm{O}_{3}-\mathrm{CeO}_{2}$ mixed oxide system prepared by the impregnation of boehmite with cerium nitrate and followed by calcinations. ${ }^{14,15)}$ However, the toluene conversion efficiency of the studied samples was still slightly lower than that observed for active $\mathrm{CeO}_{2}$ catalyst. ${ }^{8)}$ From above studies, the highest catalytic activity in both $m$-xylene and toluene combustions obtained for the sample calcined at $450^{\circ} \mathrm{C}$ in comparison to that of other bee's nest-like nanostructured samples calcined at 600,750 and $850^{\circ} \mathrm{C}$ might be attributed to its largest average pore size of $800 \mathrm{~nm}$. 

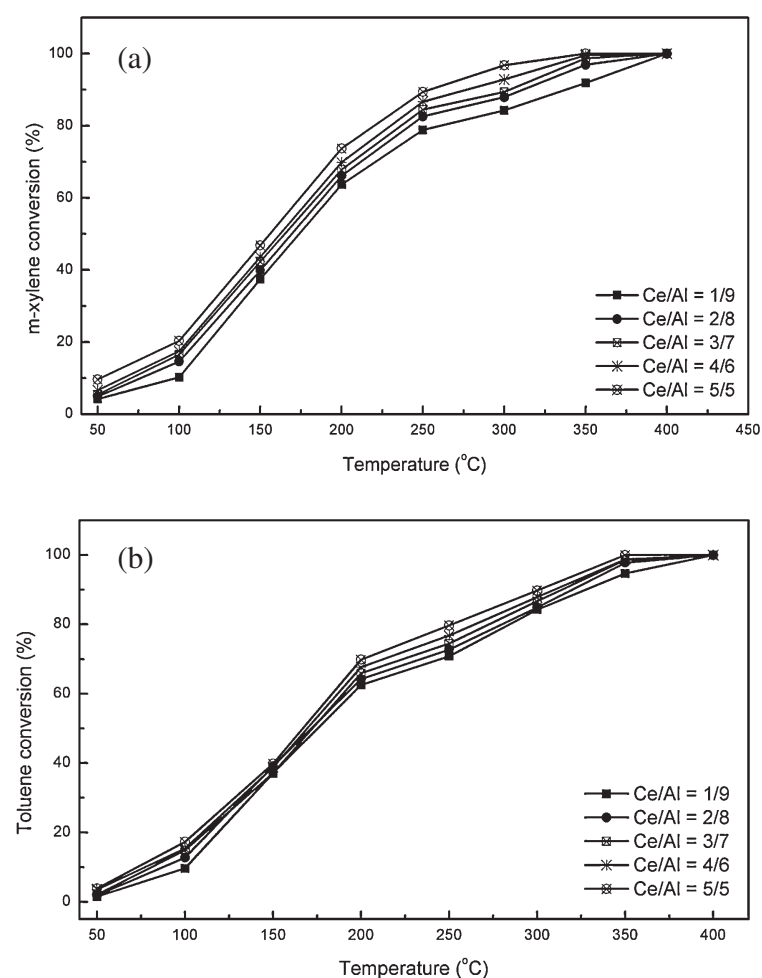

Fig. 3 Catalytic conversion of (a) $m$-xylene and (b) toluene over nanostructured $\mathrm{CeO}_{2}-\mathrm{Al}_{2} \mathrm{O}_{3}$ powders calcined at $850^{\circ} \mathrm{C}$ with $\mathrm{Ce} / \mathrm{Al}$ molar ratio of $1 / 9,2 / 8,3 / 7,4 / 6$ and $5 / 5$.

\subsection{Effects of Ce/Al molar ratio on the $m$-xylene and toluene conversion}

In order to investigate the effects of $\mathrm{Ce} / \mathrm{Al}$ molar ratio on the $m$-xylene and toluene conversion, we intend to select $\mathrm{CeO}_{2}-\mathrm{Al}_{2} \mathrm{O}_{3}$ mixed oxide powders that exhibit a stable bee's nest-like nanostructure and well-defined fluorite structure $\mathrm{CeO}_{2}$-based phase. From the results reported in our previous work, ${ }^{16)}$ it was clear that the sample calcined at $850^{\circ} \mathrm{C}$ is the only one that possesses both the bee's nest-like nanostructure and the pure fully crystallized fluorite structure $\mathrm{CeO}_{2}$-based phase. Hence, the samples calcined at $850^{\circ} \mathrm{C}$ with the $\mathrm{Ce} / \mathrm{Al}$ molar ratio of $1 / 9,2 / 8,3 / 7,5 / 5$ and $4 / 6$ were subjected to catalytic activity tests for $m$-xylene and toluene combustion (Figs. 3(a) and 3(b)). The results showed that, the lowest required temperatures for $90 \%$ conversion of $m$-xylene and toluene were 250 and $300^{\circ} \mathrm{C}$, respectively, and was found in the sample with $\mathrm{Ce} / \mathrm{Al}$ molar ratio of $5 / 5$. Thus, for the case of toluene conversion, the optimized $\mathrm{Ce} / \mathrm{Al}$ molar ratio was found for the lowest catalytic reaction temperature and this differs from the previous work, ${ }^{15)}$ in which the lowest value of catalytic reaction temperature was achieved with the highest $\mathrm{Ce} / \mathrm{Al}$ ratio.

\section{Conclusion}

In conclusion, the bee's nest-like nanostructured $\mathrm{CeO}_{2}-$ $\mathrm{Al}_{2} \mathrm{O}_{3}$ powders were successfully synthesized by combustion method using polyvinyl alcohol as a fuel was studied. Results showed that, for the samples calcined at temperatures in the range of $450-850^{\circ} \mathrm{C}$, the catalytic reaction temperature increased monotonically from 200 to $250^{\circ} \mathrm{C}$ and from 250 to $300^{\circ} \mathrm{C}$ for the $90 \%$ conversion of $m$-xylene and toluene, respectively. For these combustions, the sample calcined at $450^{\circ} \mathrm{C}$ with a bee's nest-like nanostructure and average pore size of $800 \mathrm{~nm}$ exhibited the highest catalytic activity. Among the samples with different investigated $\mathrm{Ce} / \mathrm{Al}$ molar ratios of $1 / 9,2 / 8,3 / 7,4 / 6$ and $5 / 5$, the lowest catalytic reaction temperature for the $90 \%$ conversion of $m$-xylene and toluene of 250 and $300^{\circ} \mathrm{C}$, respectively, was found with the sample having the equimolar ratio of $\mathrm{Ce} / \mathrm{Al}$. From these promising results, it is quite possible to use the bee's nest-like nanostructured $\mathrm{CeO}_{2}-\mathrm{Al}_{2} \mathrm{O}_{3}$ powders as catalyst for elimination of $m$-xylene and toluene as well as other volatile organic compounds.

\section{REFERENCES}

1) J. C. S. Wu, Z. A. Lin, F. M. Tsai and J. W. Pan: Catal. Today 63 (2000) 419-426.

2) S. Al-Khattaf, M. N. Akhtar, T. Odedairo, A. Aitani, N. M. Tukur, M. Kubů, Z. Musilová-Pavlačková and J. Čejka: Appl. Catal. A 394 (2011) 176-190.

3) W. Xie, Y. Qin, D. Liang, D. Song and D. He: Ultrason. Sonochem. 18 (2011) 1077-1081.

4) A. F. Pérez-Cadenas, S. Morales-Torres, F. J. Maldonado-Hódar and F. Carrasco-Marín: Appl. Catal. A 366 (2009) 282-287.

5) V. Gaur, A. Sharma and N. Verma: Carbon 43 (2005) 3041-3053.

6) I.-J. Lee, C.-H. Lee, S.-D. Lee and D. J. Suh: J. Ind. Eng. Chem. 11 (2005) 918-925.

7) L. He, Y. Yu, C. Zhang and H. He: J. Environ. Sci. 23 (2011) 160-165.

8) C.-H. Wang and S.-S. Lin: Catal. A 268 (2004) 227-233.

9) D. Yu, Y. Liu and Z. Wu: Catal. Commun. 11 (2010) 788-791.

10) R. Prasad and G. Rattan: Bull. Chem. React. Eng. Catal. 5 (2010) 7-30.

11) U. Menon, V. V. Galvita and G. B. Marin: J. Catal. 283 (2011) 1-9.

12) Y. Chen, S. Zhu, T. Qiu and S. Chen: Catal. Commun. 11 (2009) 20-23.

13) P. A. Deshpande, S. T. Aruna and G. Madras: Catal. Sci. Technol. 1 (2011) 1683-1691.

14) Z. Abbasi, M. Haghighi, E. Fatehifar and S. Saedy: J. Hazard. Mater. 186 (2011) 1445-1454.

15) G. Del Angel, J. M. Padilla, I. Cuauhtémoc and J. Navarrete: J. Mol. Catal. A: Chem. 281 (2008) 173-178.

16) D. N. Nhiem, L. M. Dai, Ng-D. Van and D. T. Lim: Ceram. Int. 39 (2013) 3381-3385. 